症例

超音波内視鏡下吸引細胞診が有効であった非機能性膵島細胞腫の 1 例

岐阜大学高度先進外科学, 西美濃厚生病院外科*

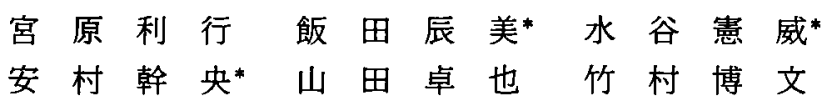

非機能性膵島腫湯は比較的稀な疾患であり，ホルモン過剩分泌による症状を呈しない ため, 早期発見が困難な場合が多く，また術前診断が困難であることが多い. 本腫湟は 切除により良好な予後を得られることから，早期発見かつ術前診断を得ることが重要で ある. 今回, 最大径 $1.5 \mathrm{~cm}$ で発見し, 超音波内視鏡下吸引細胞診で術前診断を得た非機 能性膵島腫瘍を経験したので報告する. 症例は68歳, 女性. 肝硬変に対する治療のため 通院中, 精査のため腹部 MRI・CT を施行された時に, 膵腫瘍を指摘され, 精查加療目 的で入院した，身体所見では大きな異常はなく，内分泌機能検查ではガストリンの軽度 上昇とグルカゴンの軽度低下認めた。画像診断では, 典型的な脺島腫腸の像を呈し, 超 音波内視鏡下吸引細胞診にて病理組織学的診断を得ることができた。術前診断を得るた めに, 安全でかつ簡便な超音波内視鏡下吸引細胞診は極めて有効な検査である.

索引用語 : non-functioning islet cell tumor, endoscopic ultrasound-fine needle aspiration, preoperative diagnosis

\section{緒言}

非機能性膵島腫瘍 (non-functioning islet cell tumor)は比較的稀な疾患であり，ホルモン過㮃分泌に よる症状を呈しないため，早期発見が困難な場合が多 く，また術前診断が困難であることが多い．本腫瘍は 92\%が覀性であるという報告”があるが，切除により 比較的良好な予後を得られることから，早期発見かつ 術前診断を得ることにより的確な治療が可能である。 最大径 $1.5 \mathrm{~cm}$ で発見し, 超音波内視鏡下吸引細胞診で 術前診断を得た非機能性膵島腫瘍を経験したので報告 する。

$$
\text { 症例 }
$$

症例：68歳, 女性.

主訴：なし.

既往歴：慢性心不全, 喘息, 肝硬変, 胆豪摘出術 $(58$ 歳), 腰部交感神経節切除術 (36歳, 40歳)

家族歴：特記事項なし。

現病歴：肝硬変に対する治療のため通院中, 精查の

2005年 7 月 15 日受付 2005 年10月26日採用

〈所属施設住所〉

厂501-1194 岐阜市柳戸 1-1
ために施行された腹部 MRI・CT で，膵腫嗱を指摘さ れ，精査加療目的で入院した。

入院時現症：体格中等, 栄着状態良好. 眼瞼結膜に 賓血，眼球結膜に黄疸は認めず．腹部は平坦軟で圧痛 はなく，腫瘤も触知せず．手術創を 3 力所認めた。表

\section{表 1 術前血液検查}

\begin{tabular}{lrrlrr}
\hline WBC & 8,300 & $/ \mathrm{mm}^{3}$ & GOT & 57 & $\mathrm{Iu} / 1$ \\
RBC & $412 \times 10^{4}$ & $/ \mathrm{mm}^{3}$ & GPT & 45 & $\mathrm{Iu} / 1$ \\
$\mathrm{Hb}$ & 14.3 & $\mathrm{~g} / \mathrm{dl}$ & LDH & 487 & $\mathrm{Iu} / 1$ \\
$\mathrm{Ht}$ & 40.2 & $\%$ & ALP & 186 & $\mathrm{Iu} / 1$ \\
PLT & $20.6 \times 10^{4}$ & $/ \mathrm{mm}^{3}$ & T. Bil & 0.9 & $\mathrm{mg} / \mathrm{dl}$ \\
& & & T.P & 6.2 & $\mathrm{~g} / \mathrm{dl}$ \\
PT & 97.8 & $\%$ & Alb & 3.7 & $\mathrm{~g} / \mathrm{dl}$ \\
APTT & 31.9 & 秒 & BUN & 9 & $\mathrm{mg} / \mathrm{dl}$ \\
& & & Cre & 0.7 & $\mathrm{mg} / \mathrm{dl}$ \\
エラスターゼ & $383 \mathrm{ng} / \mathrm{ml}$ & T-cho & 189 & $\mathrm{mg} / \mathrm{dl}$ \\
CA19-9 & 5 末満 & $\mathrm{U} / \mathrm{ml}$ & AMY & $174 \mathrm{Iu} / 1,37 \mathrm{C}$ \\
AFP & $21 \mathrm{ng} / \mathrm{ml}$ & Na & 141 & $\mathrm{mEq} / 1$ \\
CEA & $4.9 \mathrm{ng} / \mathrm{ml}$ & $\mathrm{K}$ & 3.5 & $\mathrm{mEq} / 1$ \\
DUPAN-2 & 410 & $\mathrm{U} / \mathrm{ml}$ & Cl & 102 & $\mathrm{mEq} / 1$ \\
インスリン & $13.9 \mu \mathrm{g} / \mathrm{ml}$ & Ca & 9.8 & $\mathrm{mEq} / 1$ \\
ガストリン & $230 \mu \mathrm{gg} / \mathrm{ml}$ & FBS & 92 & $\mathrm{mg} / \mathrm{dl}$ \\
グルカゴン & $31 \mu \mathrm{g} / \mathrm{ml}$ & CRP & 0.01 & $\mathrm{mg} / \mathrm{dl}$ \\
\hline
\end{tabular}



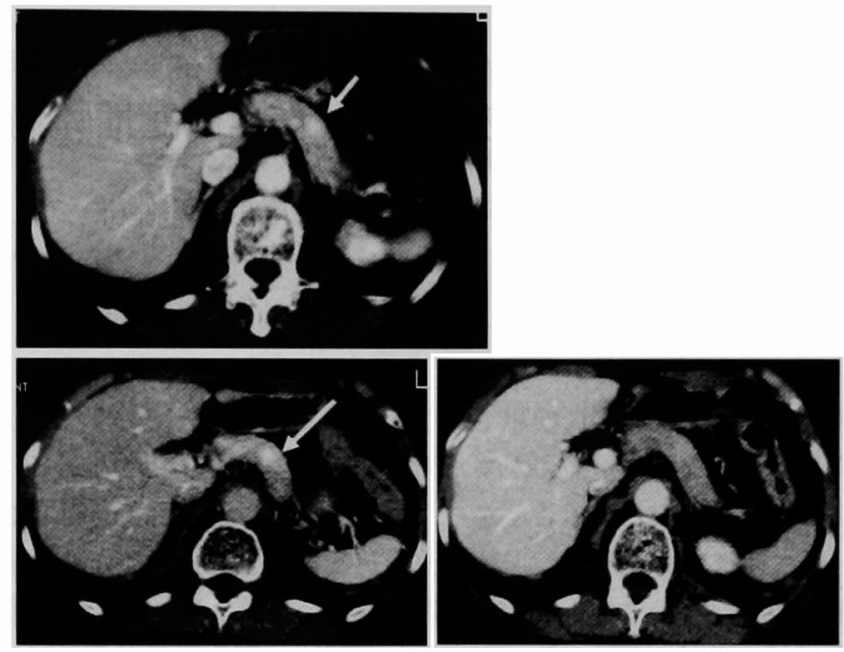

図 1 腹部 CT 検査：造影 CT では膵体部に早期相で濃染される腫 瘤影を認める. CTA では同部位に強く造影効果を認める. CTAP では造影効果は認めない.

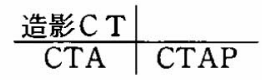

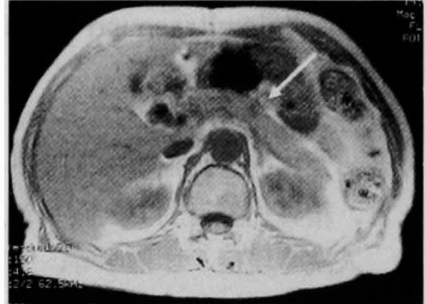

T1WI-in phase

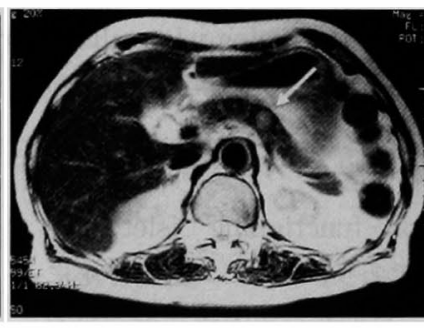

T2WI

図 2 腹部 MRI 検査：T1 強調画像で膵体部に低信号の腫瘤影を, T2 強調画像で高信号の腫瘤影を認める.

在リンパ節は触知せず。

術前血液検查: 肝酵素と血清アミラーゼ値の軽度上 昇を認めた。腫瘍マーカーも AFP $21 \mathrm{ng} / \mathrm{ml}, \mathrm{CEA} 4.9$ $\mathrm{lg} / \mathrm{ml}$, DUPAN-2 410U/ml (150U/ml 以下) といず 几も軽度の上昇を認めた。内分泌機能検査ではガスト リン $230 \mu \mathrm{g} / \mathrm{ml}(200 \mathrm{pg} / \mathrm{ml}$ 以下) と軽度上昇, グルカ コン $31 \mu \mathrm{g} / \mathrm{ml}(40 \sim 180 \mathrm{pg} / \mathrm{ml})$ と軽度低下認めた（表 $1)$.

胸腹部単純 $\mathbf{X}$ 線検査：胸部，腹部ともに異常を認め なかった。

腹部造影 CT 検查：早期相で膵体部に造影効果のあ 了腫瘤影を認め(図 1 ), 後期相では膵実質と等濃度と なった，CTAでは，同部位に強く造影効果を認めた。

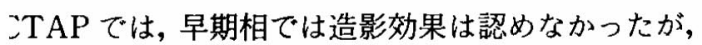

後期相では淡く造影された（図 1).

腹部 MRI 検查 : T1 強調画像で膵体部に低信号の 腫瘤影を, T2 強調画像で高信号の腫瘤影を認めた(図 2 ). 脂肪抑制効果は認めなかった. MRCPでは脺管, 胆管ともに拡張・狭窄を認めなかった。

腹部血管造影検查：腹腔動脈造影で膵体部に腫煌濃 染像を認めた(図 3 )。上腸間膜動脈造影では, 門脈相 も含め異常は認めなかった。

内視鏡的逆行性膵管造影検査 (ERP)：主膵管に異 常を認めなかった。

超音波内視鏡検査（EUS）：膵体部に境界明瞭な $11.7 \times 15.3 \mathrm{~mm}$ の内部均一な低エコーの腫瘤を認めた

(図 4 ). 同時に施行した吸引細胞診で class III, 膵島 細胞腫裼と診断した（図 4). 
以上から, 非機能性膵島細胞腫瘍の診断で, 悪性例 も多いことから”脺体尾部切除術を第 1 選択とした。

手術所見：開腹時少量の腹水認めた，腹水細胞診は class I であった. 肝は軽度硬化していたが, 腫瘤は認 めなかった。萃体部に $1 \mathrm{~cm}$ 大の腫瘤を触知し, 術中超 音波検查では低エコー腫瘤であった。脾動脈周囲リン パ節腫脹を数個認めた。脺体尾部・脾合併切除術を施 行した.

摘出標本所見：膵体部に径 $1 \mathrm{~cm}$ 大の球状の境界明 瞭な腫瘤を認め，割面は白色で硬い腫瘤であった。主 膵管との交通は認めなかった（図 5 )。

病理組織学的検査：腫瘍はリボン状構造をとった膵 島細胞よりなり,周囲との境界は明瞭であった(図 5 )。 リンパ節転移は認めなかった。

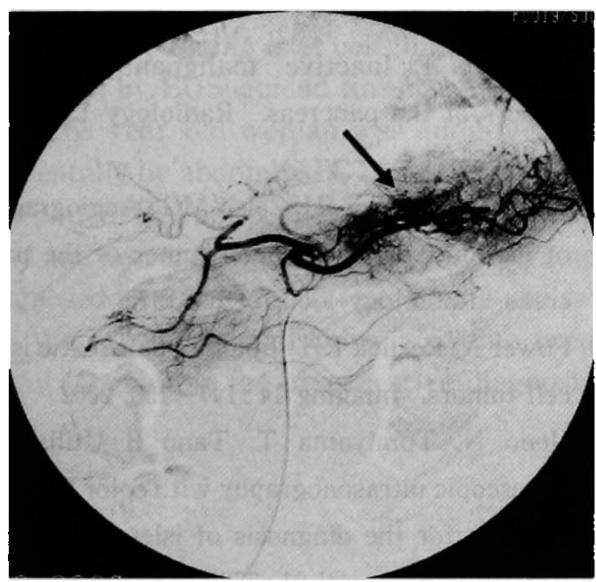

図 3 腹部血管造影検査：腹腔動脈造影で膵体 部に腫偒濃染像を認めろ。

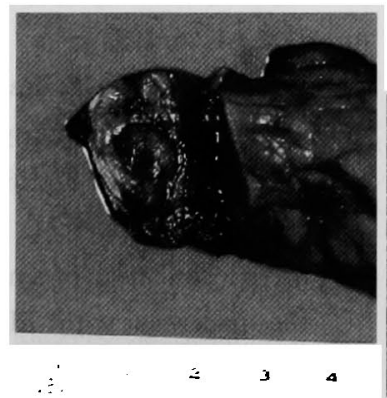

考察

膵島腫湟は，機能性腫瘍と非機能性腫瘍とに分けら れており，症例の症候と血中の内分泌機能の動態から 判定して，ホルモン異常が認められないものを非機能 性膵島細胞腫とされている2．膵島腫瘍のうち非機能 性膵島細胞腫の占める割合は15〜30\%といわれ(1)3，特 異的な臨床症状を有する機能性脺島腫瘍に比へ，非機 能性膵島腫演はホルモン過剩分泌による症状を呈しな いため，早期発見および術前の質的診断を下すことが 困難である，近年，画像診断の向上により症例数が増 加し, 術前診断が可能な症例数も増加している。しか し, 病理組織学的な術前診断が得られる症例は稀であ る.

非機能性膵島腫瘍は, Kent ら 56.8 歳, 男女比は $1 ： 3$ で臨床症状は腹痛, 黄疸なと が多く，無症状のものも $16 \%$ と報告している．本症例
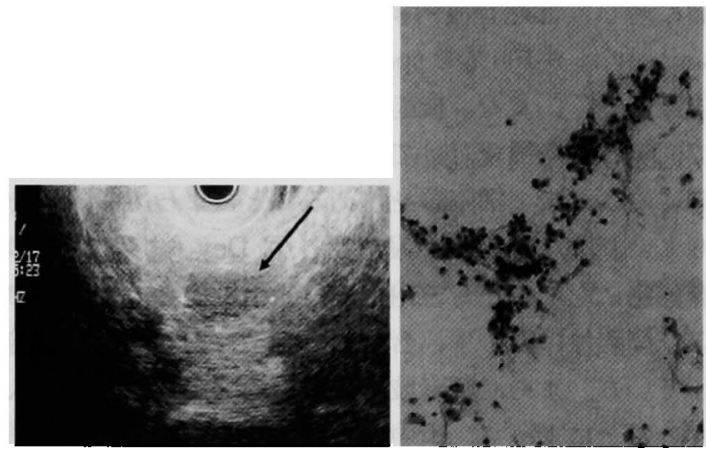

図 4 左 超音波内視鏡検査 (EUS)：膵体部に $11.7 \times 15.3$ $\mathrm{mm}$ の内部均一の低エコーの腫瘤を認める。

右 吸引細胞診：脺島細胞を認める. class III, 膵島 細胞腫瘍と診断された。

図 5 左 摘出標本所見：膵体部に径 $1 \mathrm{~cm}$ の球状の腫瘤を認め，割面 は白色で硬い腫瘤である。主膵管との交通は認めない.

右 病理組織学的検査 $(\mathrm{HE}$ 染色 $\times 40)$ : 腫瘍は, リボン状構造を

とった脺島細胞からなり，周囲との境界は明暸である。 
無症状であったが，その理由として非機能性膵島腫 昜は腫瘍が存在する場所や大きさによる症状, 所見(腹 甬，黄疸，腫瘤触知など）しか呈しないことによると 夲えられる。

画像診断上の特徵は hypervascular な腫㾤であり， 3aghery ら“は腹部血管造影の所見として，1) hyperascularity, 2 ) vascular displacement, 3 ) pathologcal vessels を挙げている。单純 CTでは脺実質と等濃 复で, 造影 CT では動脈早期相より強濃染される腫瘤 上して描出される，腫瑒の増大に伴い中心壊死をきた 一, 後腹膜への浸潤，石灰化は悪性を示唆する所見と るる5. 本症例でも, 腹部造影 CT 検査で早期相にて造 効果のある腫瘤影を認め, CTAでは同部位に強く 告影効果を認めた。また，腹腔動脈造影では腫瘍濃染 象を認めた. MRI 検查では，本症例と同様に $\mathrm{T} 1$ 強調 画像で低信号, T2 強調画像で高信号の腫瘤となる また，他の検査では，見落とされがちな $2 \mathrm{~cm}$ 以下の腫 留に対しては超音波内視鏡検查が特に優れており ${ }^{51}$, ensitivity が100\%で specificity が95\%であるとの報 声もある ${ }^{677}$. また，機能性膵島腫湢40人に対する検討 で，超音波内視鏡だけでは擬陽性思者が $28 \%$ \%っった Dに対し，吸引細胞診を加えることによって擬陽性を $0 \%$ に制限したという報告もあり,Dey ら ${ }^{8)}$ も，14例の 萃腫場に対する超音波内視鏡下吸引細胞診で擬陽性お 上び擬陰性は認めず，合併症も1例もなかったと報告 している，また，超音波内視鏡下で腫湯に色素を注入 することによって, 術中における腫潢の局在診断の補 由になり得るとの報告もある9!。

本症例ではガストリンの軽度上昇, グルカゴンの軽 文低下を認めたものの, ホルモン過剩分泌による症状 を全く呈していなかった，肝硬変の治療中に施行した ンT, MRI 検査で偶然脺腫湯を発見することができ，典 型的な画像所見から膵島腫瘍を疑いつつ, 超音波内視 竟下吸引細胞猃で病理組織学的診断を得ることができ 上.

正確な術前診断を得ることができ，小病変の描出に も優れている超音波内視鏡および超音波内視鏡下吸引 田胞診は脺腫瘤の極めて有効な検査法であることが示 夋された。

本疾患は悪性例が $92 \%$ との報告もあり，正確な術前 参断に上る適切な術式を選択することが必要である。 また，本疾患の予後は Dial ら ${ }^{10)}$, Brougham ら ${ }^{11} は$ は, 5 年生存率は63\%であるが, 転移がなく原発巣を完全 刀除された場合の 5 年生存率は $77 \%^{12)}$ と報告してお $\eta$, 早期診断と積極的な外科的切除が不可欠と考えら れる. 本症例では脾動脈周囲リンパ節の腫脹を認め, リンパ節郭清を含め膵体尾部・脾合併切除術を選択し た.リンパ節転移の有無が正確に早く診断可能ならば, 脾を温存した腫瘤核出術も選択肢となりうると考えら れた.

\section{結 語}

術前診断が可能であった，非機能性膵島腫湯の 1 例 を経験した。詳細な術前診断を得るために, 超音波内 視鏡下吸引細胞診は安全で簡便で有効な検查法であ る.

\section{文献}

1) Kent $R B$, vein Heeden JA, Lee $A K:$ Nonfun. ctioning islet cell tumors. Ann Surg 193 : 185190, 1981

2) 亀山徹：膵内分泌腫瘍の病理. 病理と臨 2 : 432-439, 1984

3) Boijisen $E$ : Inactive malignant endcrine tumors of the pancreas. Radiology $15: 177-$ 182. 1975

4) Baghery S, Alfidi RJ, Zelsh MG : Angiography of nonfunctioning islet cell tumor of the pancreas. Radiology $120: 57-59,1976$

5) Power $N$, Reznek RH : Imaging pansreatic islet cell tumors. Imaging $14: 147-159,2002$

6) Ueno $N$, Tomiyama $T$, Tano $S$ : Utility of endoscopic ultrasonography with color Doppler function for the diagnosis of islet cell tumor. Am J Gastroenterol 91 : 772-776, 1996

7) Rosch T, Lightdale CJ, Botet JF : Localization of pancreatic neuroendocrine tumors by endoscopic ultrasonography. N Engl J Med 326: 1721-1726, 1992

8) Dey P, Radhika S, Rajwanshi A, et al: Fine needle aspiration biopsy of pancreas. Indian $\mathrm{J}$ Pathol Microbiol 37 : 269-274, 1994

9) Gress FG, Barawi M, Kim D, et al: Preoperative localization of a neuroendocrine tumor of the pancreas with EUS-guided fine needle tattooing. Gastrointestinal Endoscopy $55: 594$ $-597,2002$

10) Dial PF, Braasch JW, Rossi RL, et al : Management of nonfunctioning islet cell tumors of pancreas. Surg Clin North Am 65:291-295, 
1985

11) Brougham TA, Leslie JD, Soto JM, et al : Pansreatic islet cell tumors. Surgery $99: 671-678$, 1986

12) Carmen CS, Jeffrey EL, Peter WTP, et al:
Nonfunctioning islet carcinoma of the pancreas; Survival results in a contemporary series of 163 patients. Surgery $130: 1078-1085$, 2001

\title{
A CASE OF NON-FUNCTIONING ISLET CELL TUMOR OF THE PANCREAS DIAGNOSED WITH ENDOSCOPIC ULTRASONOGRAPHY (EUS)-GUIDED FINE-NEEDLE ASPIRATION BIOPSY
}

\author{
Toshiyuki MIYAHARA, Tatsumi IIDA*, Noritake MIZUTANI*, \\ Mikio YASUMURA*, Takuya YAMADA and Hirofumi TAKEMURA \\ Advanced Surgery, Graduate School of Medicine, Gifu University \\ "Department of Surgery, Nishimino Kosei Hospital
}

Non-functioning islet cell tumors of the pancreas are relatively uncommon. Because these tumors lack hormone-related symptoms, early diagnosis is difficult. Prognosis after surgical resection is generally good, so that early detection as well as preoperative diagnosis is important. We report a case of a non-functioning islet cell tumor of the pancreas detected in the maximum diameter of $1.5 \mathrm{~cm}$ and diagnosed by EUS-guided fine-needle aspiration biopsy.

A 68-year-old woman was admitted to the hospital for treatment of a pancreatic tumor detected incidentally by abdominal CT and magnetic resonance imaging scans during treatment for liver cirrhosis. The patient had no specific clinical symptoms, and an endocrine function test showed an increased gastrin level and decreased glucagons level. By imaging studies, the tumor was a typical islet cell tumor and was diagnosed by EUS-guided fine-needle aspiration biopsy.

We conclude that EUS-guided fine-needle aspiration biopsy which is safe and convenient is very useful for making the preoperative diagnosis of non-functioning islet cell tumors. 